\title{
FORAGE CROPS: THEIR PLACE IN GRASSLAND FARMING
}

\author{
By R. H. BEVIN, Executive Officer, N.Z. Meat and \\ Wool Boards' Economic Service.
}

With our system of grassland farming in New Zealand, and with the emphasis placed on the relation'ship between the grazing animals and the pasture in which they run, we have been tending in recent years to modify our farm-management methods. We have to some extent forgotten or temporarily mislaid some of the older traditional practices. In particular there has been an evident avoidance of the need for forage crop provision, and today, in the North Island, only 1 acre in 30 of our arable land is under the plough each year. This means in effect that our pastures on the average are 20 to 30 years old before they are broken up and resown.

In this paper I propose to deal with this aspect of our pasture management, and. the part which the growing of forage crops should play in the grassland utilisation scheme of the arable country, if, as a further advance, we consider seriously stepping up our production by renewing the swards. regularly, increasing the output per acre of butterfat, meat, and wool, and providing adequately in the process for feed during periods of pasture shortage.

In his work on the dry-matter production of pastures in seasonal periods Lynch shows clearly the shortages in feed which may be anticipated.

In the Waikato approximately 45 per cent. of the growth occurs in spring, 30 per cent. in summer, 13 per cent. in autumn, and about the same in winter.

In the Stratford area the growth in spring, summer, and autumn shows little variation in 'the average year, but there is a distinct feed shortage in winter15 per cent. of total production.

In .Poverty Bay the main shortage in the average year occurs in autumn, there being a close similarity between winter, spring, and summer production.

In the South Island generally there are two main 
divisions : Southland experiences fairly uniform production in spring, summer, and autumn, but, in the winter dormant period the production from pasture is 5 per cent. or less of the year's total. In Canterbury there is a flush of growth in spring and early summer, a falling away in'late summer and autumn, followed by low production in winter.

These variations in production demand a good, deal of judgment in both the regulation of stock numbers and in the utilisation of grass as and when it is available. In both summer and winter, depending on climate, soil type, and geographical situation, efficient stock management demands that we give consideration to the provision of supplementary feed during those periods when seasonal pasture growth is insufficient for stock needs. While shortage of summer feed calls for attention in some districts, the wintering problem is of more general application throughout the Dominion.

Every endeavour is made by the more progressive farmers to encourage pasture growth late in autumn and early in spring in order to get as close as possible to the "12-months-grass" feeding policy, and so reduce to a minimum the need for the cultivation for forage crops and the conservation of hay and silage.

In a few well-favoured districts stock may be carried through the year without recourse to supplementary feeding. As the climatic or geographical conditions render this policy more of a gamble risks are taken ; in good years results are satisfactory, and in bad years the stock suffer and production falls. In those districts where there is no question about it the provision of supplementary forage is taken as a matter of course and the routine farm programme provides for a cultivation and/or fodder conservation scheme which operates year in, year out.

By special management techniques, including topdressing, controlled grazing, and periodic spelling of pastures, much has been done to employ pasturage to advantage, and so reduce the periods of seasonal shortage to a. minimum. Growth is prolonged into winter, spring recovery is accelerated', and cold storage, plus rationing of grass available, has narrowed down the winter shortage considerably, even in the colder districts. But it is questionable if we can avoid entirely the need for supplementary forage crops if we are determined to pursue a policy of maximum farm production. 
In recent years the attaining of a "stocking balance" on farms has been determined, to a great extent, by the physical abilities of the farmer and his farm labour to cope with the work involved. During the last 10 years the tendency has been to reduce manual work incidental to crop production to a minimum, because of labour difficulties. This reduction of manual work has, however, been accompanied by an increase in mechanisation, and this in turn has given us a new approach to the question of cultivation, Men and horses have been reduced in number, but the introduction of the tractor has more than replaced them in working capacity, so that it is possible to review the question of forage crop growing in the light of the ease of working which the mechnical developments of recent years have provided.

There are two main objectives in the growing of forage crops. One obviously, is the feeding of sheep and cattle during the winter and/or summer months. The second objective is the breaking up of our older pastures and their renewal with new strains of grasses and clovers.

The better feeding of stock in winter pays dividends in higher returns and lower losses ; this applies equally to sheep and cattle. In the former, feed shortage about lambing time-i.e., early spring-may lead to considerable stock losses in both ewes and lambs, and in lowering the fleece weight and quality, while with dairy cows good feeding about calving time is usually followed by a longer period of sustained high production.

It is equally important in many districts to consider the shortage of pasture growth in the mid-December-January period, when the dominantly ryegrass pasture tends to slump in most years. In the northern districts paspalum is available to take up the running, but further south it is difficult to fill the gap, although special-purpose pastures of the timothy-cocksfoot-dominant type might be useful. At the moment, however, one of the most satisfactory methods of maintaining the flow of milk or of topping off, lambs in the autumn is by the use of forage crops.

It is probable that in the North Island, where the emphasis on dairying is so marked on our better grassland country and where the winter is not so severe or prolonged as in the south, the summer forage crop may come to be regarded as that best suited to 
prepare land for pasture replacement. Forage crops grown in the spring and fed off in summer leave the ground ready for autumn sowing of new pasture, which, if well established and properly managed, will provide a wealth of late winter and early spring greenfeed. Where the area available is satisfactorily related to stock numbers this green feed may well displace the roots or silage more commonly used today.

But whether we are growing forage for winter or summer, one fact requires stressing. For good crop production fertility must be high and the ploughing of good grass swards pays dividends in the correspondingly high yields of forage resulting. Paddocks reserved for ploughing up are too often allowed to deteriorate so that ploughing is regarded as a necessary evil. A sounder approach, and this has been proved both experimentally and in the field, is to regard the vigorous sward as the natural prelude to a healthy, highly-productive forage crop which, while it may skim off some of the accumulated fertility of the rich pasture land, leaves ample in reserve for vigorous young growth of. the newly sown pasture which follows.

The renewal of pastures has tended to be neglected over the last two decades or so, mainly because the emphasis has been on the improvement of existing pastures by topdressing. Such improvement has, over most of our easier country, been of a most payable

nature. Nevertheless we must now recognise that since the days when improvement of this type began the plant breeder has been busy and today we have at our disposal improved strains of grasses and clovers which it has been shown can outyield the old pastures in dry matter production. The replacement of loweryielding species by the new strains is the next forward step in our grassland progress if we are to exploit to the full the fertility of our soils, the fruits of years of painstaking research, and our managerial skill as graziers.

If we take the figures of forage crops grown as an indication of the pasture renewal which is taking place in New Zealand, it can be seen that there is ample scope for an enlargement of our present policy.

In 1948-49 the record shows approximately 700,000 acres of forage crops; of this, 500,000 acres were grown in Canterbury, Otago, and, Southland, leaving some 200,000 acres for the North Island. In Canterbury, Otago, and Southland there are $5 \frac{1}{2}$ million acres arable, 
so approximately one-tenth is under the plough for forage. In the North Island there are also $5 \frac{1}{2}$ million acres arable, of which only 1 acre in 30 is under cultivation for forage crops.

From observations made, and from the experience of those farmers who have tried it, there is ample evidence to support the policy of providing chou moellier and/or greenfeed as a supplement, to pastures in the winter-early spring period. The subsequent pastures resulting from the resowing show a considerable increase in productivity over the old pastures, and it must be recognised that all this increase in productivity represents profit to the farmer, provided of course that full use is made of the increased pasture growth.

Finally, one might comment on the economic side of this question of ploughing up and resowing pastures, using the forage crop as an intermediate stage between the old sward and the new.

Most farmers, with present prices for butterfat, meat and wool are satisfied with the returns from the average good pastures of our dairying and fat-lamb 'farms. To break up such, pastures and resow them is a costly operation-estimates vary from $£ 8$ to $£ 12$ per acre, depending on circumstances-and there is not yet established the conviction that the increased productivity reported by the grassland research workers will be reflected under average farming conditions.

But gradually the more progressive pioneers are launching out and in a few years' time the uncertain approach of the present will be replaced by the confidence which experience and observation of a wide range of farming trials under varying conditions will give to the farmers in the future, This has been the pattern of all our forward movements in pasture and stock management, and doubtless the replacement of our present pastures will follow the same path.

From the roughly-grazed, indifferent pastures of 30 years ago we have, by the widespread use of fertilisers, by subdivision on rational lines, by controlled grazing, and by better utilisation of the pasture growth throughout the year-by all these modifications of farm management we have built up the grassland wealth of the Dominion. With further potential production waiting to be exploited when the " $10,000 \mathrm{lb}$. of dry-matter sward" is replaced by the " $15,000 \mathrm{lb}$. pasture," it is almost certain that in due course, given the incentive to further increase production, the grassland 137. 
farmers of the country will eventually exploit the possibilities which the improved grass and clover strains offer. And in the management technique essential to ensure full utilisation of the regularly renewed, young, vigorous pastures, there must be included the use of forage crops to bridge the gaps which accompany the seasonal productivity cycles to which our perennial pastures are subject over the year.

\section{DISCUSSION}

Q. Is not the "grass to grass" system of pasture establishment better than the growing of crops when a good ryegrasswhite clover sward is turned over in 'summer and sown in autumn.

A. Where the fertility is high and the land reasonably clean, as it would be where a good ryegrass-white clover sward is turned under, the grass to grass practice is very satisfactory. Ploughing is done at a time when feed is plentiful. A larger area can be tackled, and so the rate of regrassing with improved

, species can be accelerated. Given good seed-bed conditions, a fairly high proportion of short-rotation ryegrass in the mixture, and ample fertiliser, the new grass gets away rapidly and provides good greenfeed in winter and early spring.

Q. Should nitrogenous fertilisers be used with forage
crops?

A. It is all a question of cost, but where poor swards are turned under there will probably be a shortage 'of organic nitrogen. The application of nitrogenous fertiliser will help to grow a vigorous leafy fodder crop, which, by producing more feed, carries 'more stock and so has a greater return of dung and urine to the land. Subsequent shallow working on this consolidated land, followed by sowing of grass, should result in a denser and more vigorous pasture than that resulting from a poor, unthrifty forage crop grown on lower fertility soil with low nitrogen supplies. Adequate fallowing and fertilising of the forage crop to make it worthwhile for the feeding of stock and for the build up of surface fertility for subsequent grass growth should be the aim of the farmer using forage crops in the pasture and animal cycle. 